\title{
Improving the Quality of Academic Services in Higher Education by the Development of SIMANTAP
}

\author{
Enjang Yusup Ali ${ }^{1, *}$, M. Munir ${ }^{2}$, Johar Permana ${ }^{1}$, Dedy Achmad Kurniady ${ }^{1}$ \\ ${ }^{1}$ Department Administrasi Pendidikan, Universitas Pendidikan Indonesia, Indonesia \\ ${ }^{2}$ Department Ilmu Komputer, Universitas Pendidikan Indonesia, Indonesia
}

Received October 24, 2019; Revised December 24, 2019; Accepted December 30, 2019

Copyright $\bigcirc 2020$ by authors, all rights reserved. Authors agree that this article remains permanently open access under the terms of the Creative Commons Attribution License 4.0 International License

\begin{abstract}
Universities as educational providers need to provide good academic services for students. Academic services in the 4.0 era can be provided by creating an internet-based academic system. When a university does not have an internet-based academic service system, the university cannot provide good and quality academic services. This article aims at developing and analyzing academic services at universities by using an internet-based academic service system and Enterprise Architecture (EA). An academic service system called SIMANTAP (Sistem Informasi Manajemen Akademik Terpadu/Integrated Academic Management Information System) was made to implement in the academic service system at a university. The research method used was design-based research using the stages of defining, designing, developing, and reflecting. The research was conducted at four faculties at one university in West Java Province, Indonesia, which did not have an internet-based academic service system. The results showed that the utilization of academic service systems in universities has an important role in the process of conducting academic activities both for students, lecturers, and university staff. The academic activities were greatly helped by the use of internet-based academic service system. In its implementation, all users needed to know more and get used to using it, and the system designer needs to be responsive to anticipate any weaknesses in the system so that the academic service process runs well continuously.
\end{abstract}

Keywords Academic Services, Service Quality, SIMANTAP, Enterprise Architecture

\section{Introduction}

Academic services are important factors in the process of carrying out activities at universities. In fact, obtaining quality academic services has become students' right (Hossain \& Ahmed, 2014). Various staff and lecturer activities are basically influenced by the quality of service at the university (Del-Palacio, Sole, \& Berbegal, 2011). The availability of good education facilities and management is one of the important factors to improve the quality of academic services (Ruhyana \& Aeni, 2019; Sunaengsih, Anggarani, Amalia, Nurfatmala, \& Naelin, 2019). In this 4.0 era, it is common for universities to have sophisticated internet-based systems or Enterprise Architecture (EA) to handle academic services. However, in reality, there are still many universities especially in Indonesia that have not had internet-based academic services. As a result, various problems arise such as data errors during student registration, difficulties in data synchronization of students who have paid tuition fees and those who have not, chaos in scheduling lectures due to clashes of time and space for lectures, and repeated input of student grades due to missing files or improper archiving.

Therefore, it is necessary to make a good internet-based academic service system to handle academic service issues at universities (Burnett, Shemroske, \& Khayum, 2014). This study aims at dealing with problems that arise in academic services by creating and developing an academic service system called SIMANTAP (Sistem Informasi Manajemen Akademik Terpadu/Integrated Academic Management Information System) in the environment of university named Institut Agama Islam Cipasung (IAIC) located in West Java Province, Indonesia. This system was developed to serve students better as customers at the university in order to satisfy them in academic services. Thus, students are expected to be able to carry out the registration process, study well, and obtain transcripts easily.

Considering the increasing significance of services, several studies have been conducted. A study presented at the ATEM "Student Service Centres" conference in August 2006, has taken into account the characteristics of 
'customer' and 'customer service' in the higher education context. Nowadays, researchers have focused mainly on the relationship between general staff and students as external customers, and general staff and academics as internal customers (Pitman (2000). Several researches about the relationships have shown consistent results. Regarding the students, there is a growing characteristic that students are customers of special kind. They suggested that general staff understand their main role to provide services to students, but they see that these services are only in the university environment, and they are not the same as other customer services. Szekeres (2006) found somewhat a disagreement to the idea that students are 'customers' in the modern university. Likewise, Pitman (2000) discovered that the general staff did not want to consider students as customers and they often choose to refer to students just as 'students' or, in some cases, they prefer the term 'clients' rather than 'customers'. This shows that the staff views their relationship with the students as in a pastoral model rather than as in a transaction-based approach usually found in the private sector customer service. Guilbault (2016) recommended that the staffs explore ways to think of students as customers rather than denying that they are customers.

Additionally, the general staff supports the academic staff in a range of functions. The academic and student support services can help the academic staff to make the most of their time to do research, teach, and do governance activities. Regarding the rocketing academic workload over the past decade (Anderson, Johnson, \& Saha, 2002; Winefield, Gillespie, Stough, Dua, \& Hapuararchchi, 2002), it is important to have strong administrative support systems. For instance, student service staff offers direct and indirect services to lessen the academic staffs' administrative workload. Direct services cover tasks such as servicing committees, processing results, and collating data on student issues. While indirect services cover tasks that release academic time or resources, such as giving the students quasi-academic advice on degree progression. Researches have shown that by providing administrative services, general staff tend to regard the academic staff members as 'internal' customers. Academic staff members are considered as customers because they receive service, but they are different from external customers because of they are within the institution and they are expected to have ongoing working relationships (Conway \& Dobson, 2003). On the subject of customer service, literature suggested that general staff are often viewed and, certainly, usually view that one of their roles is to provide service for academic staff as their customers (McInnis, 1998).

Other past research also showed significant findings in the topic of academic service. Small (2008) examined how general staff from an academic and student services unit consider their role within a large metropolitan university. Focus groups and interviews with student and academic services staff concluded that their relationships with clients and as clients are not straightforward or without problems. However, it appears that that they have optimism for the future and goodwill towards other staff. This has become a strong basis for more efforts to improve efficient and effective relationships between various university staff groups. Investments made by universities in general staff, and the assistance that the staff provide, guarantee a better understanding of these staff instead of only the simple dichotomy of 'academic' and 'general' in the existing literature.

Hatziconstantis and Kolympari (2016) studied the success of the Creativity, Action, and Service (CAS) components (now revised as Creativity, Activity, and Service), which was based on experiential learning philosophy and Academic Service Learning. In the research, they used mixed content analysis technique to find out students' perception in an International Baccalaureate Greek private school concerning the implementation and effectiveness of CAS. The empirical results showed that the students had views and concepts of volunteering activities in two different dimensions: idealistic-humanitarian and utilitarian-instrumentalist, which implied that Academic Service Learning projects needed to be adjusted to reach their goals.

Dominguez-Whitehead (2018) presented students experience with non-academic support services. The research was conducted at two universities in South Africa, which was based on the perspective of organizational theory. The findings indicated that students' interactions with the people in charge of providing non-academic services are considered as giving low standard services. The research subjects' statements were analyzed and it was discovered that the subjects made critical explanations for the low standard services received.

Recent research by Knight-McKenna, Hollingsworth, and Ammerman (2019) investigated the effect of academic service-learning (ASL) on undergraduate students' knowledge, skills, and viewpoint on cooperating with families with various cultural and linguistic backgrounds to improve young children's early academic learning. The subjects were nine undergraduate students in preparation course of early childhood teachers, ten families with diverse cultural and linguistic background, and thirteen children of 2- to 5-year-old. This mixed-methods research analyzed the written student ASL reflections, pre- and post-ASL student surveys, and parent evaluations. The analysis found three themes: (1) Students had ASL experience excitedly and approached positively; (2) Students were apparently very nervous and uncomfortable as well as felt difficulties in the partnership-building in the early- to mid-semester, but they also show interest in the family and engagement; and (3) Most students, in the midto late-semester showed more confidence in their skills to relate with to diverse families, and they could identify family strengths. The findings supported that ASL is an effective way to prepare teachers to help students build 
partnerships between families and teachers.

To fill the gap that has not been done by previous research, this study is focused on developing an academic service system with the aim of supporting and improving the quality of academic services. Research is limited to the problem of how an internet-based system can help carrying out academic services, from conducting student registration to obtaining grade transcripts.

\section{Theoretical Framework}

Two significant aspects that become the foundation in this study are the information system service quality and academic service system quality. The quality of academic service in university is heavily influenced by the provision of facility and the established ability in managing these two aspects.

\subsection{Information System Service Quality}

There have been a number of researches on information system, which focuses on the measurement of system success and its influencing factors. The information system has developed in response to the advancements in computer and information technology, hence, the research focusing on information system evaluation has accordingly shifted. Year to year, the discussion was varied. In the 1970s, the quality of hardware and software on information system became the focus of discussion (Delone \& McLean, 2003). Meanwhile, in the 1980s, information system success measures and the relationship between user satisfaction and system use were disputed in much discussion (Jang, Kim, \& Hwang, 2006). Then, studies on information system evaluation in the 1990s grew by adopting the ideas of "service quality," which mostly used in the marketing domain (Petter, DeLone, \& McLean, 2013). Even though the research focus on information system has expanded in response to the varied objective and context of research, the essence of studies in information system research still emphasizes on the effectiveness and efficiency of information system to measure and factors to improve in ensuring the success of system (DeLone \& McLean, 1992; Urbach \& Müller, 2012).

DeLone and McLean reviewed the studies of Weaver and Shannon (1949) and Mason (1978) (Diavastis, Anagnostopoulou, Drogalas, \& Karagiorgos, 2016), which resulted in a model of information system success (DeLone \& McLean, 1992; Jang et al., 2006). The D\&M IS Success Model identifies six factors aim at measuring the level information system success, (i.e., system quality, information quality, use, user satisfaction, individual influence and organization influence) and portrays the causal relationships among these factors. This D\&M IS Success Model has contributed significantly to the research on information system evaluation seen from the perspective of large amount of research that can be carried out to confirm and/or expand the model. Furthermore, there are several empirical research that have verified the original model (Ballantine et al., 1996; DeLone \& McLean, 2002; Ishman, 1996). Meanwhile, others disputed the model validity and suggested revised models (Myers, Kappelman, \& Prybutok, 1997; Rai, Lang, \& Welker, 2002; Seddon, 1997; Seddon, Staples, Patnayakuni, \& Bowtell, 1999). One of critiques focuses on distinguishing the noticeable factors related to system success, while ignoring the measurement of each factor. Another argument disputes that the model does not elaborate the outcomes clarity of system success by combining individual and company level success in the same model (Gregor, 2006; Hevner, March, Park, \& Ram, 2004). Therefore, four factor model that includes system quality, information quality, user and user satisfaction was proposed by Seddon (1997) to prevent unnecessary confusion (Wade \& Hulland, 2004). In a similar vein, Saarinen (1996) inserts the aspect of process and product to the model, while Myers et al. (1997) add the model expansion by including service quality (Ahn, Ryu, \& Han, 2007; Gable, Sedera, \& Chan, 2008).

DeLone and McLean extended their original model in 2013 by considering the major critiques on their model and deliberating the recent technological developments. The updated D\&M IS Success Model results in three important quality factors of an information system (i.e., information quality, system quality, and service quality), which could influence users' intention to use, actual use, and user satisfaction. The information quality represents the significance of information, which becomes fundamental due to the increased costs of obtaining information within the context of the information system management (Bailey \& Pearson, 1983; Legris, Ingham, \& Collerette, 2003; Miller \& Doyle, 1987; Nelson, Todd, \& Wixom, 2005; Srinivasan, 1985; Straub, Limayem, \& Karahanna-Evaristo, 1995). In addition, system quality is linked to the technology used in information systems defining the interaction method between system and user (Bailey \& Pearson, 1983; Kettinger \& Lee, 1994; Srinivasan, 1985). Besides, the service quality signifies the suitability of tangible or intangible outcomes of information system (Akbaba, 2006; Bhattacherjee, 2001; Bouman \& Van der Wiele, 1992; Caruana, 2002; Pitt, Watson, \& Kavan, 1995). Meanwhile, the system use and user satisfaction are mostly used as dependent variables in evaluating information system (Bailey \& Pearson, 1983; Baroudi \& Orlikowski, 1988; Brancheau \& Brown, 1993; Davis, 1989; Dillon \& Morris, 1996; Galletta \& Lederer, 1989; Moore \& Benbasat, 1991; Venkatesh, Morris, Davis, \& Davis, 2003). Seeing from the perspective of relationship between system use and user satisfaction, DeLone and McLean postulate a reciprocal relationship instead of a uni-directional relationship in their model. In relation to this issue, it is believed that the system used should precede 
user satisfaction seen from the perspective of process and positive experience with the system use, in order to achieve greater user satisfaction in a causal sense (Ein-Dor \& Segev, 1978; Thong, 1999). At the same time, increased user satisfaction with the system means intention to use is increased, which resulted in actual use (Guimaraes \& Igbaria, 1997; Sabherwal, Jeyaraj, \& Chowa, 2006). Furthermore, system use and user satisfaction would acquire "net benefits" of information system. In contrast to their original model, DeLone and McLean have not differentiated individual level benefits from company level benefits to reduce the confusion produced by having outcomes at different levels, which allow a broader range of application of the model (Jang et al., 2006).

\subsection{Academic Service System Quality}

Traditionally, research, teaching and learning activities define what a university is and does (Robertson \& Bond, 2001; Romainville, 1996). However, providing high quality student and academic services starts to be considered as an increasingly important responsibility of the modern university. Over the past decade, the political and financial imperatives of the 'enterprise university' (James, 2002; Marginson \& Considine, 2000) have shifted to be vital in university priorities. In accordance with the development in managerialist techniques, the new functional areas of universities have increasingly emphasized on commercial practices and standards. Consequently, there has been a growing concern on the issues of student and customer service from this process. The government of Indonesia, through the audit institution, has implemented an assessment on the academic service quality to their students. One of the important aspects assessed is how the service for students can become more convenient through academic system developed through internet network and online service

The government's pressure has raised the university dependence on income generated from students, which encourage them to enhance student services. The high competitive student recruitment environment has created a reputation that quality services are fundamental to be distinctive and competitive institution. In many universities, there has been an insight that students are increasingly acting as 'customers' who expect a high level of services in return for their fees (Eagle \& Brennan, 2007;
Sharrock, 2000). Today's students experiencing significant increases in the higher education fees and costs often reserve the right to be entitled in receiving commensurate increases of the service provided.

In regards to the importance of service quality, Doll and Torkzadeh (1988) affirm that it is the basic concept for user's satisfaction (Doll \& Torkzadeh, 1991). However, the reality shows that the apparent consideration of service quality in the domain of information system evaluation has just occurred recently. In particular, the current information system evaluation models emphasize on products' capability rather than on the service quality of information system (Bhattacherjee, 2001; Pitt et al., 1995). As response, Kettinger and Lee (1994) have signified the fundamental influence of the service provided by information service providers in order fulfill users' satisfaction in an organization (Kettinger \& Lee, 1997). Furthermore, the evaluation of system quality is focused on system performance, convenience, system development process, etc. (Bailey \& Pearson, 1983; Srinivasan, 1985). Lee and Pow (1996) recommend that user satisfaction is linked to system quality, which can be seen from the convenience of reaching, convenience of learning/using system, user's restriction, flexibility, and system consistency (Au, Ngai, \& Cheng, 2002; Hussain, Taylor, \& Flynn, 2004).

\section{Methods}

\subsection{Research Design}

This study is a development study using Design-Based Research (DBR) with stages referring to Amiel and Reeves (2008). There are four stages in designing an academic service system as depicted in Figure 1, which includes: 1) identifying and analyzing of the problem (defining), 2) designing the solution (designing), 3) repeating the cycles in testing and perfecting the design (developing), and 4 ) reflecting to produce the principles of design and implementation (reflecting). The study was conducted in four faculties at one of the universities in West Java Province, Indonesia. The chosen university is a university that did not have an online or internet-based academic service system.

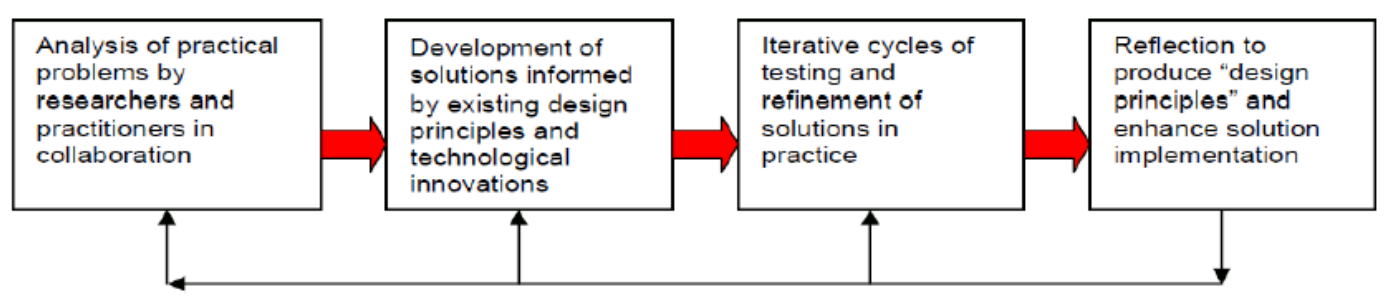

Figure 1. Stages of DBR (Amiel and Reeves, 2008) in developing academic services system 
The system development process involved several academic elements, namely the rector as the policy maker to develop the academic service system, the vice-rector as supervisor and coordinator of activities, deans, heads of study programs, lecturers, academic staff, and students as users of the academic service system. The feasibility or quality of the academic service system was also assessed by a team of experts in the IT field.

\subsection{Research Site and Participants}

This study was conducted in one of the IAICs located in West Java Indonesia. IAIC is one of Islamic university that manages pesantren as an education and regeneration basis with the spirit of integration of religion science and general knowledge. The participants involved in the implementation of SIMANTAP are 20 universities representatives consisting of administrative staffs, lectures, and heads of universities, also 100 representatives of students. The university representatives were surveyed about the intensity, interest in utilizing SIMANTAP, ability in using computer and internet to support SIMANTAP. Meanwhile, students were surveyed about their satisfaction toward SIMANTAP.

\section{Results}

\subsection{Defining}

At this stage, problems in the quality of academic services were identified and analyzed by using questionnaires distributed to students, educational staff, and lecturers as users of academic service quality. The results of identification and analysis revealed several problems as follows.

\subsubsection{Analysis of Student Data}

There were errors in student data due to the manual collection of student biographies. The impacts were duplicate student ID number and inability to submit the data to the relevant ministry because the data were incomplete. Therefore, it was necessary to input student data online to have a database that was centralized, complete, and could be obtained or submitted quickly.

\subsubsection{Analysis of Financial Data}

There were difficulties in identifying and synchronizing data of students who have already registered or paid tuition fees and those who have not. The problem was detected when many students were registered as active, yet the amount of tuition received by the university did not match the number of students who were active. Therefore, an online tuition payment system was needed so that the data could be completely received and properly archived.

\subsubsection{Analysis of Class Schedules}

There was chaos in class scheduling such as two courses in the same room and time. The impact was the disruption of the teaching and learning process because they had to find another room for studying. Therefore, it was necessary to arrange schedules using an internet-based system so that mapping of rooms and lecture time could be done appropriately, so that clashes in the schedule can be avoided.

\subsubsection{Analysis of Student Grade}

Student grades as the results of learning were inputted manually so that errors often occur in inputting the grades. Students also found it difficult to access or find out grades quickly. There was also a loss of grades files so the lecturers had to re-input the grades. Therefore, it was necessary to input grades online so the data could be stored securely on the server and students could access grades quickly.

\subsection{Designing}

\subsubsection{Drafting Process of Academic Service System}

Analysis results of the needs of academic service systems identified three main groups of problems in the quality of academic services. These problems consist of: 1) data, which included aspects of knowledge warehouse, database \& data marts, and data interchange; 2) system, which included aspects of information systems, websites, and desktop applications; and 3) technology, which also included aspects of information systems, websites, and desktop applications. If the three problem groups were anticipated using the academic service system, it was assumed that they could be able to support the work of educators and educational staff, build good leadership in universities, facilitate the process of curriculum development, collect appropriate financial data, and improve the function of facilities in the teaching and learning process or supporting facilities.

At this stage, seven modules for an internet-based academic service system were designed. The seven modules included modules for admission of new students, student registration, course curriculum mapping, course schedules, printing study plan cards, inputting student grades, and printing study results cards or grade transcripts. 


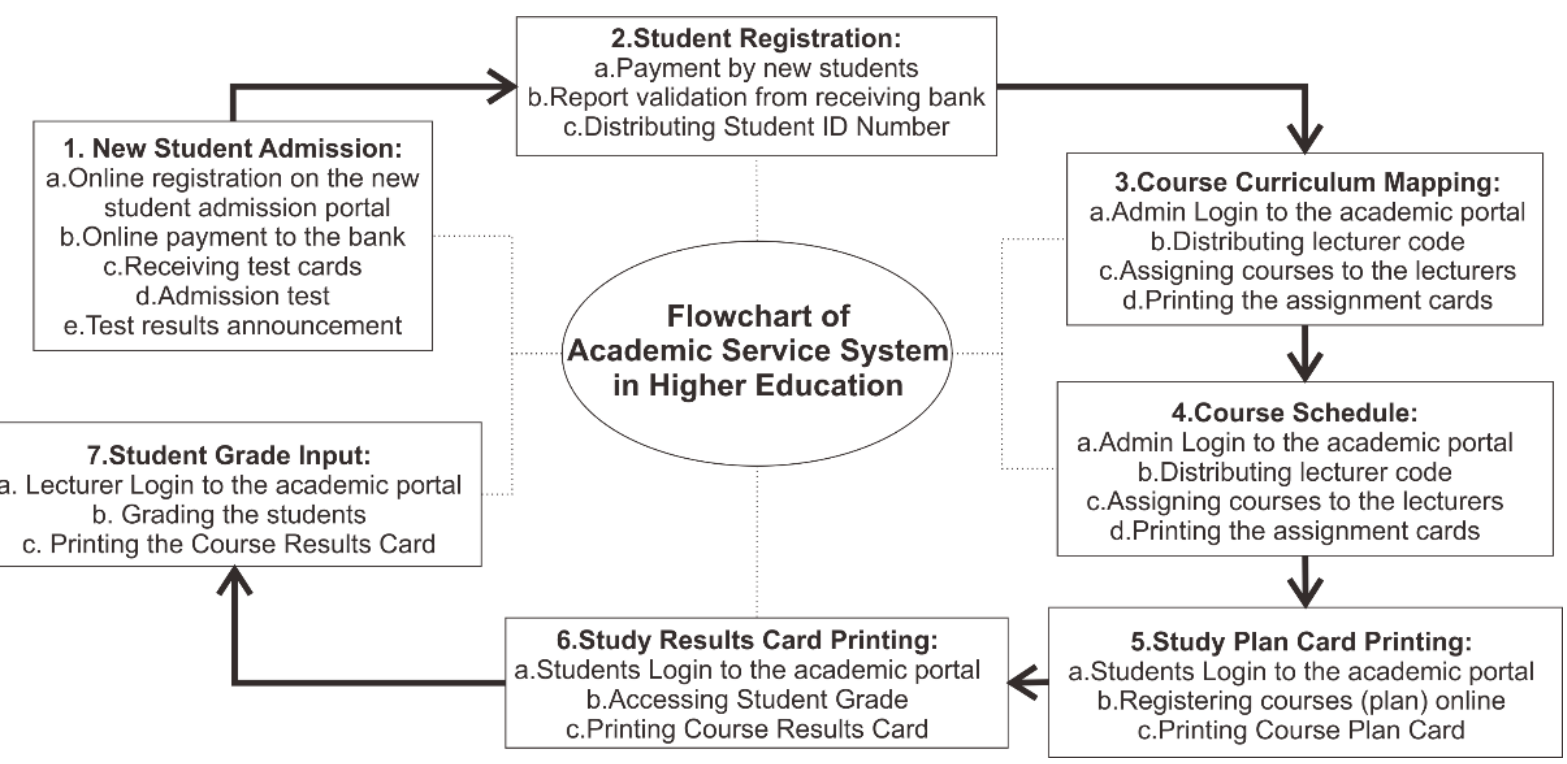

Figure 2. Draft of modules for the academic service system

\subsubsection{Results of Academic Service System}

The seven modules developed were made using PHP programming language tools and the database was created using My SQL from the local XAMPP web server tools obtained free of charge from the page https://www.apachefriends.org/index.html. Figure 3 shows the process of making modules through the local XAMPP server, creating scripts through Notepad++, and displaying modules through an intranet network. The process of making the module was: 1) installing the XAMPP application, 2) preparing programming tools and creating an application database, and 3) creating a program script. The completed modules were then uploaded to a paid hosting so that they could be accessed via the internet.

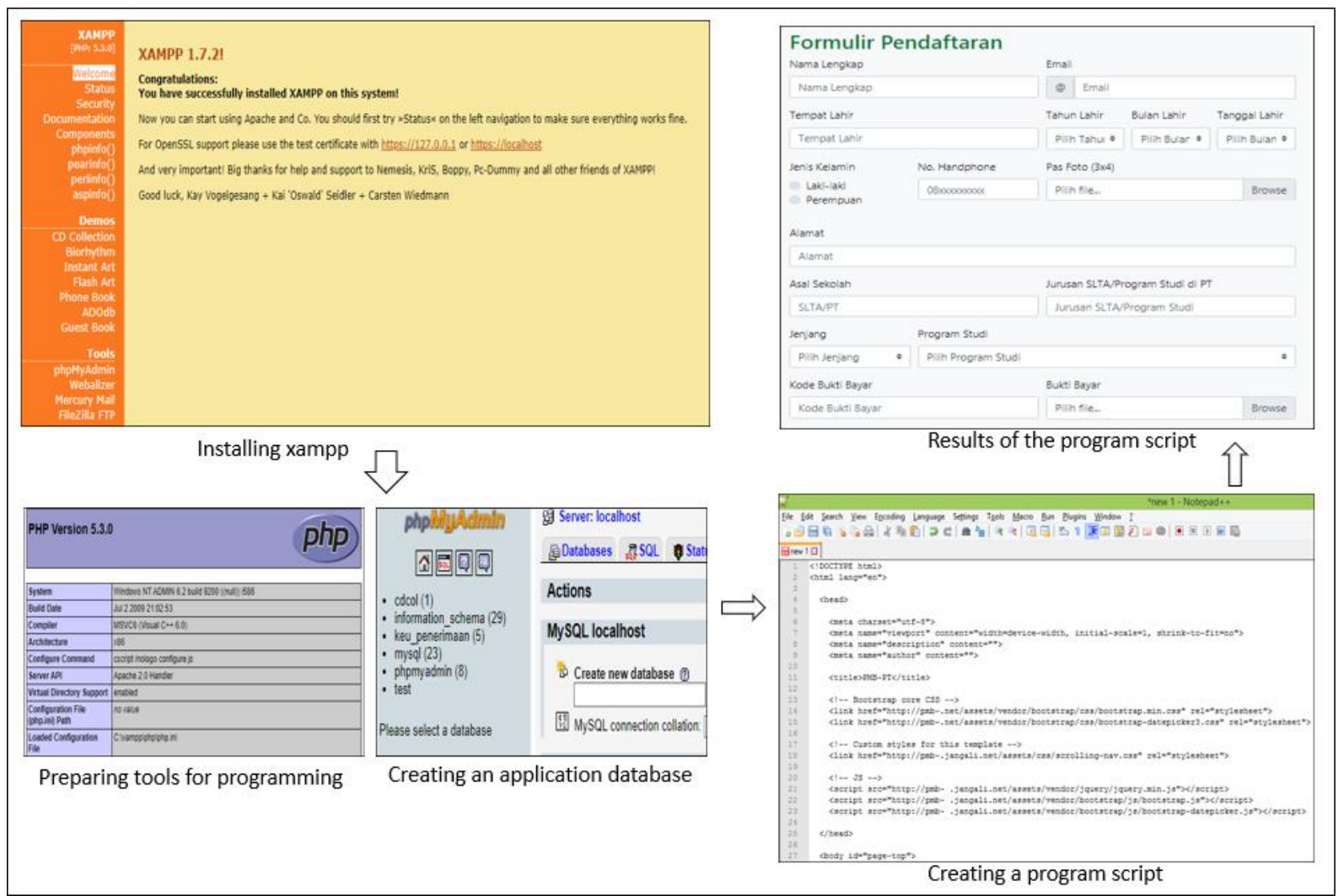

Figure 3. Making the Modules of Academic Service System 
Table 1. Results of Limited Test on the Modules

\begin{tabular}{|c|c|}
\hline $\begin{array}{l}\text { Academic Service } \\
\text { System }\end{array}$ & Problem \\
\hline Module 1 & $\begin{array}{l}\text { - The applicant data form was incomplete. } \\
\text { - In the submission of the data, there were errors in the system's recording of birth date and photograph file. } \\
\text { - There was no notification whether the data have been successfully submitted or not. }\end{array}$ \\
\hline Module 2 & $\begin{array}{l}\text { - The bank did not have the new student data. } \\
\text { - There was not a payment installment system needed by the students. } \\
\text { - The university could not receive quickly the data of paying students from the bank. }\end{array}$ \\
\hline Module 3 & $\begin{array}{l}\text { - The non-permanent lecturers did not have lecturer codes and they could not obtain teaching schedule. } \\
\text { - } \quad \text { Several courses were unavailable because of changes in the curriculum. }\end{array}$ \\
\hline Module 4 & $\begin{array}{l}\text { - There was not a way to input two lecturers in one course. } \\
\text { - There were duplicates of used classrooms }\end{array}$ \\
\hline Module 5 & $\begin{array}{l}\text { - The students who had not paid tuition could register courses. } \\
\text { - The display of the study plan card was incomplete. }\end{array}$ \\
\hline Module 6 & - $\quad$ There was no problem. \\
\hline Module 7 & - The display of the study results card was incomplete. \\
\hline
\end{tabular}

\subsection{Developing}

At this stage, the academic service system was developed through a number of trial and module revisions. The trials consisted of limited test, vast test, and validation test. The test results were also validated by a team of experts to add perfection to the academic service system.

\subsubsection{Limited Test}

The limited test was conducted at one faculty that covered module testing for the academic service system in stages starting from the admission module (Module 1), student registration (Module 2), curriculum mapping (Module 3), course schedule (Module 4), study plan card printing (Module 5), student grade input (Module 6), to study results card printing (Module 7). In the limited test, problems or weaknesses contained in the module were identified, both from the user side and from the website admin side. The results of the limited test in all modules can be seen in Table 1 .

\subsubsection{Revision based on Limited Test}

Based on the results of the limited test, problems were found in six modules, namely modules 1-2-3-4-5 and 7. The improvements to the six modules were made. Module 1 was added with facilities for completing registrant data entry, improving recording by the server on the date of birth and photo of the registrant, and adding notification about registrant data submission. Module 2 was added with a login account for the bank, tuition installment facilities, and facilities for uploading payer data from the bank. Module 3 was added with the menu to add special lecturer code for honorary lecturers, and two courses were added from the previous curriculum and the new curriculum. Module 4 was added with the menu for inputting two lecturers in one course, and a column of room and course time. Module 5 was added with the synchronization and validation menu between the registrant data, the payer data, and the course contract data, and the complete display in the study plan card namely the data of the lecturer teaching the course. Module 7 was added with the complete display in the study results card namely the data of the lecturer teaching the course.

\subsubsection{Field Test}

Field test was conducted at two faculties that covered module testing for the academic service system in stages of admission (Module 1), student registration (Module 2), curriculum mapping (Module 3), course schedule (Module 4), study plan card printing (Module 5), student grade input (Module 6), and study results card printing (Module 7). In the field test, problems or weaknesses contained in the module still existed, both from the user side and from the website admin side. The results of field test of all modules can be seen in Table 2 . 
Table 2. Results of Field Test

\begin{tabular}{|c|l|}
\hline Academic Service System & Problem \\
\hline Module 1 & The access to the system was slow when it was accessed by numerous students and lecturers simultaneously. \\
\hline Module 2 & The access to the system was slow when it was accessed by numerous students and lecturers simultaneously. \\
\hline Module 3 & The access to the system was slow when it was accessed by numerous students and lecturers simultaneously. \\
\hline Module 4 & The access to the system was slow when it was accessed by numerous students and lecturers simultaneously. \\
\hline Module 5 & The access to the system was slow when it was accessed by numerous students and lecturers simultaneously. \\
\hline Module 6 & The access to the system was slow when it was accessed by numerous students and lecturers simultaneously. \\
\hline Module 7 & The access to the system was slow when it was accessed by numerous students and lecturers simultaneously. \\
\hline
\end{tabular}

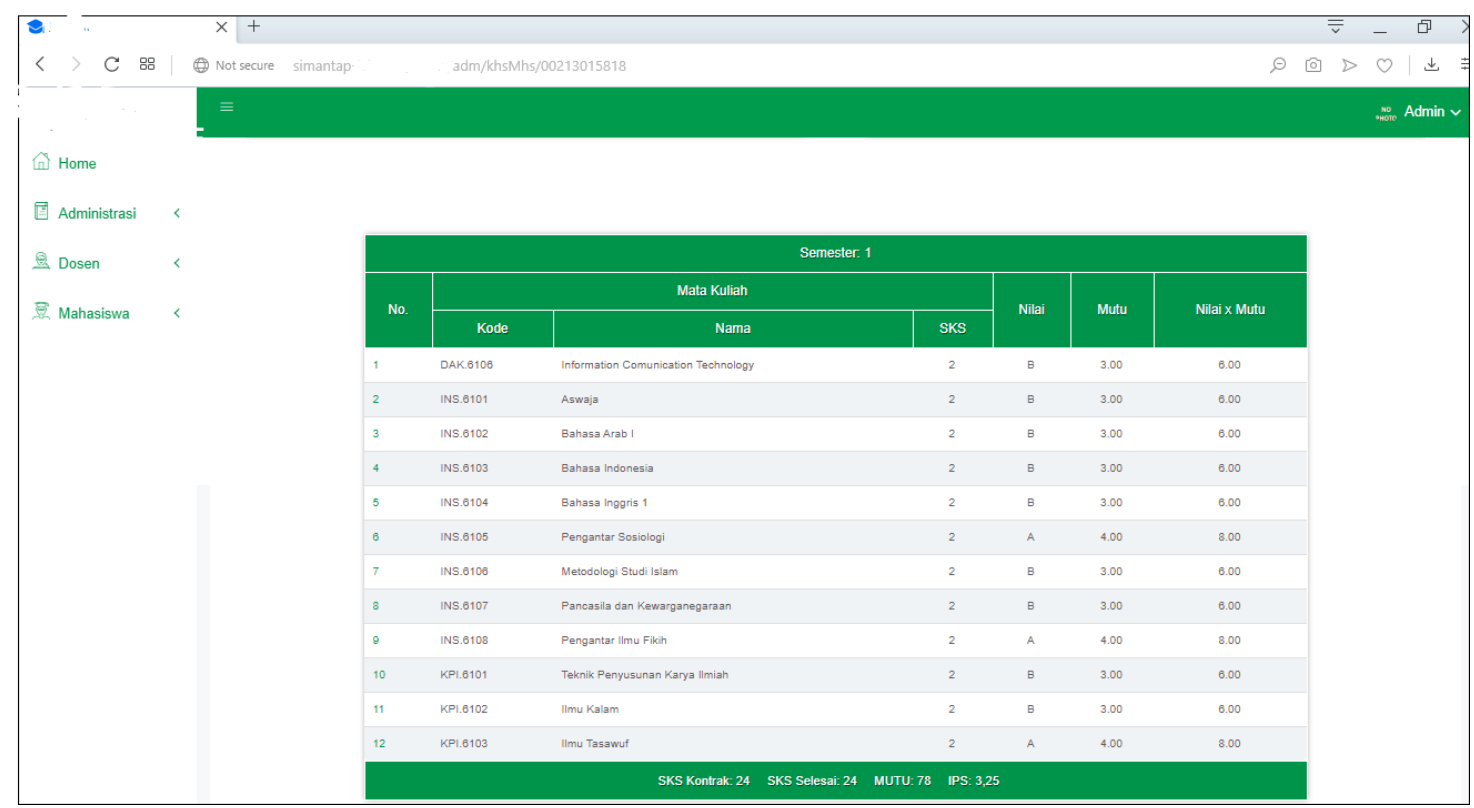

Figure 4. An Example of Academic Service System on the Study Results Card

\subsubsection{Revision Based on Field Test}

Based on the results of the field test, the problems that occurred in limited test were solved, yet new problems were found in all modules, namely slow access to the academic service system when the system was used or accessed by students in large numbers and at the same time. Improvement made to deal with this problem was to create a special path by changing the hosting to a Virtual Private Server (VPS) so that the system could be accessed without slowing down. The result was that the system became when accessed. However, in terms of financing, the cost was higher because of buying the VPS facility.

\subsubsection{Validation Test}

To identify and analyze the complete running of the modules in the academic service system, a validation test was conducted. The validation test process was carried out in one faculty by implementing the seven modules in the academic service system. The validation test results showed that all modules used for the academic service system were operating properly. Figure 4 shows an example of an academic service system from module 7 (the study results card) that was operating well.

\subsubsection{Expert Team Validation}

The academic service system that had been tested starting from the limited test to the validation test was then assessed by a team of experts totaling three people. The team of experts selected had an academic qualification in the IT field to assess aspects of efficiency, effectiveness, ease of service, data security, and others. The assessment was given within the score range of 10-100. Score under 34 is categorized as 'poor', score of 35-64 is categorized as 'inadequate', score of 65-74 is categorized as 'fair', score of 75-89 is categorized as 'good', and score of 90-100 is categorized as 'excellent'. The results of the assessment from the expert team can be seen in Table 3 . 
Table 3. Results of Expert Team Validation of the Academic Service System

\begin{tabular}{|c|c|c|c|c|}
\hline \multirow{2}{*}{ Assessment Aspect } & \multicolumn{2}{|c|}{ Academic Service System Rating Score (10 - 100) } & \multirow{2}{*}{ Average Score } \\
\cline { 2 - 4 } & Expert 1 & Expert 2 & Expert 3 & 85 \\
\hline Academic service efficiency & 90 & 75 & 90 & 85.00 \\
\hline Academic service effectiveness & 85 & 70 & 85 & 80.00 \\
\hline Convenience for staff in using academic services & 95 & 85 & 85 & 88.33 \\
\hline Convenience for students in obtaining academic services & 90 & 80 & 90 & 86.67 \\
\hline Academic data security & 90 & 70 & 80 & 80.00 \\
\hline System maintenance & 80 & 80 & 90 & 83.33 \\
\hline Speed in accessing data & 85 & 80 & 85 & 83.33 \\
\hline System user friendly & 90 & 85 & 85 & 86.67 \\
\hline Data backup system & 85 & 85 & 90 & 86.67 \\
\hline
\end{tabular}

Table 4. Result of IT Expert Team Validation

\begin{tabular}{|c|c|c|c|c|}
\hline \multirow{2}{*}{ Assessment Aspect } & \multicolumn{2}{|c|}{ Academic Service System Rating Score (10 - 100) } & \multirow{2}{*}{ Average Score } \\
\cline { 2 - 4 } & Expert 4 & Expert 5 & \multicolumn{2}{|c|}{ Expert 6 } \\
\hline Academic service efficiency & 90 & 90 & 90 & 90.00 \\
\hline Academic service effectiveness & 90 & 90 & 90 & 90.00 \\
\hline Convenience for staff in using academic services & 95 & 85 & 90 & 90.00 \\
\hline Convenience for students in obtaining academic services & 90 & 80 & 90 & 86.67 \\
\hline Academic data security & 90 & 85 & 85 & 86.67 \\
\hline System maintenance & 90 & 90 & 90 & 90.00 \\
\hline Speed in accessing data & 90 & 85 & 90 & 88.33 \\
\hline System user friendly & 95 & 90 & 90 & 91.67 \\
\hline Data backup system & 85 & 90 & 90 & 88.33 \\
\hline
\end{tabular}

Table 3 shows that the average score from the expert team ranged from 80.00 to 88.33 . This figure shows that the academic service system has been rated well in various aspects ranging from the efficiency of academic services to the data backup system. Hence, the expert team advised to continuously conduct maintenance and always update the system components such as the plug-ins. The expert team also suggested that an Android-based application be made to access the academic service system in a simpler way. An expert gave score of 75 for the aspect of academic service efficiency based on the consideration that the new online academic services was officially implemented in the second semester. The score of 70 was given in aspect of academic service effectiveness based on the consideration that online academic service was just provided for new students only, not for all the students. Meanwhile, score of 70 was given in the aspect of academic data security since the data security was still using paid web-based storage server, meanwhile an institution should have its own service to enhance the data security

Another validation was also done by asking IT experts from three other different institutions. This was done to obtain authentic assessment on the whole SIMANTAP. Table 4 presents the assessment results.

Table 4 presents that the average assessment score obtained from Expert 4-6 was in the range of 86.67-90.00. This assessment has shown that the implemented SIMANTAP at IAIC was feasible to be used as an academic service system that has good quality for several types of academic services. The IT expert team also recommended that this system should be implemented for all students and in all faculties. Using own server is also recommended to ensure and maintain the data security and confidentiality.

\subsection{Reflecting}

Together with the team of experts and related parties at the university, reflection was done on the design of the academic service system that had been created and tested, including re-analyzing various problems or potential problems that may occur in the implementation process in a wider domain. The results of the reflection produced the following points: 1) the academic service system through the use of SIMANTAP had provided convenience in the process of serving students and also facilitated work for staff at the university; 2) academic services in the university cannot be separated from the quality of integrated services ranging from the quality of academic service, the quality of input, the quality of process, the 
quality of output, and customer satisfaction that must always be maintained and improved from time to time; 3) staff and students also needed to improve their understanding of the use of internet-based academic service systems so that human errors in their implementation can be prevented. Figure 5 depicts the quality of integrated services that must be maintained starting from the quality of academic services to customer satisfaction.
The survey result obtained from university representatives on the intensity use of SIMANTAP is depicted in Figure 6. Through Likert Scale, the question raised was "Do you often use SIMANTAP?" The figure shows that there were two people $(10 \%)$ stated that they often use the system, and most of them $(n=16,80 \%)$ stated that they usually using SIMANTAP, and only two of them $(10 \%)$ rarely using the SIMANTAP.

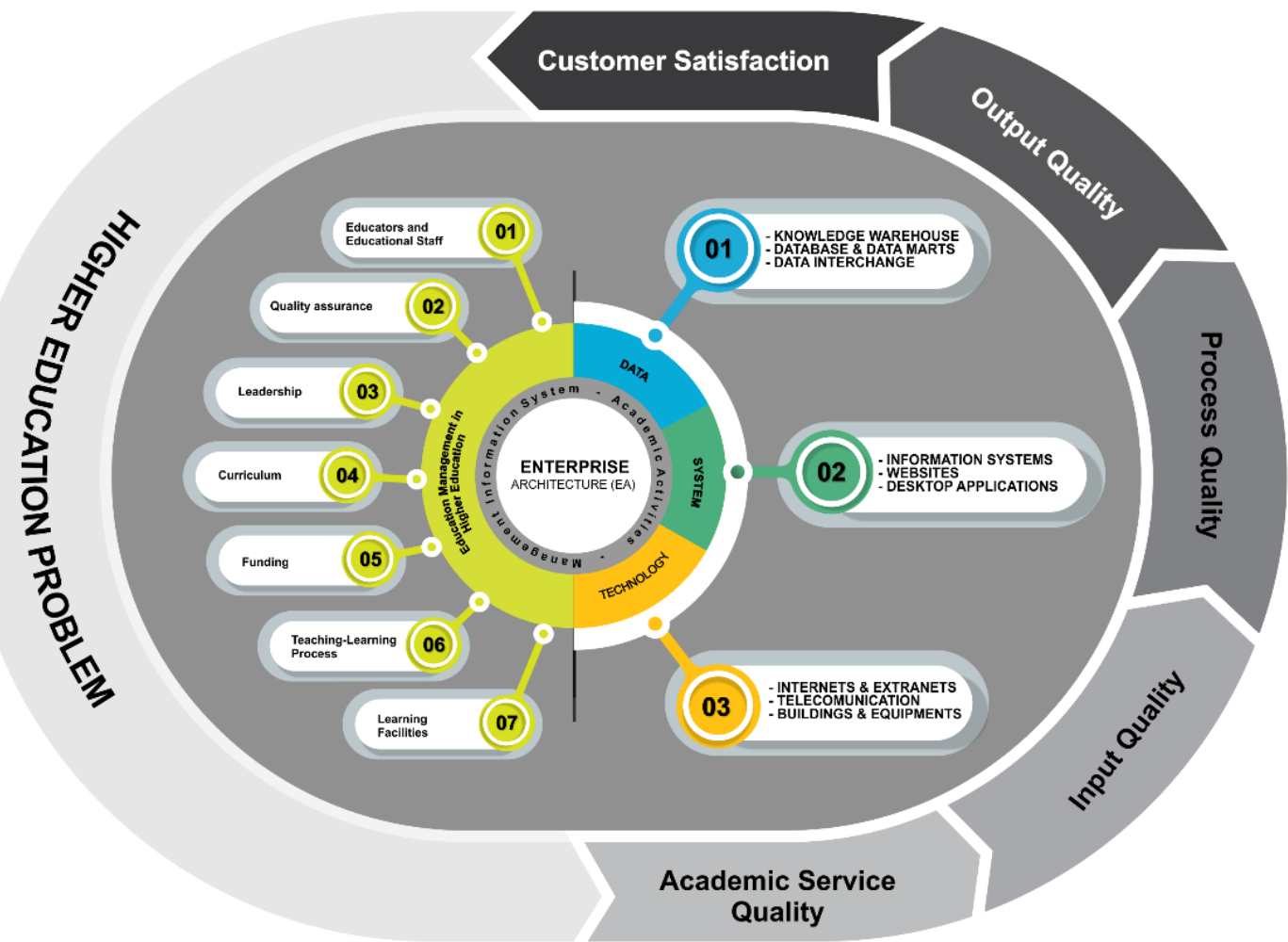

Figure 5. Academic Service System

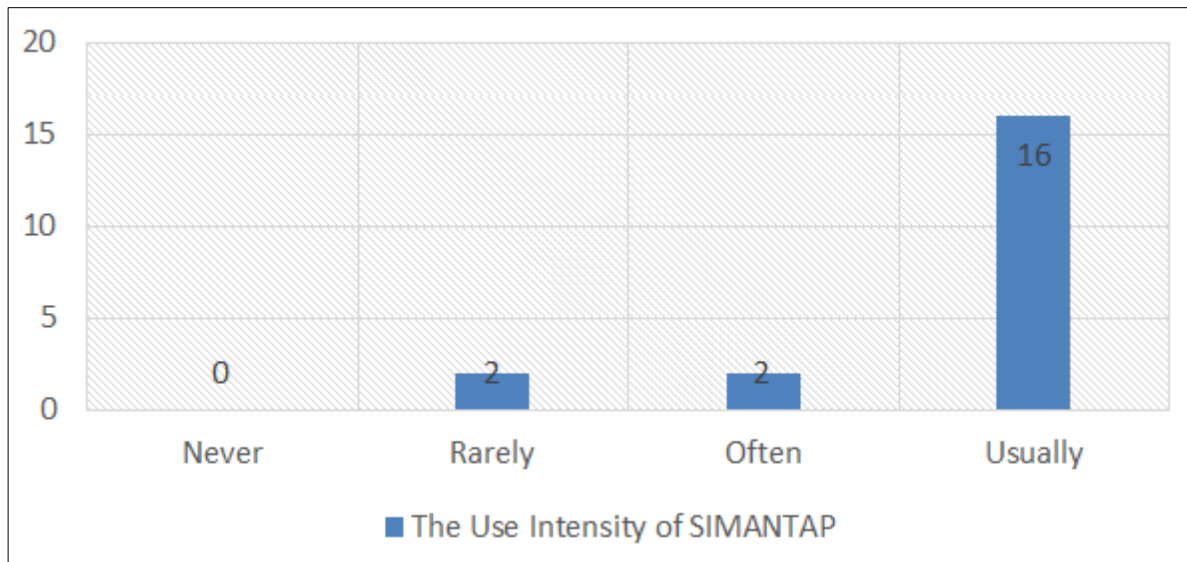

Figure 6. The Use Intensity of SIMANTAP 
The survey result on the interest of university representative on SIMANTAP was presented in Figure 7. They were asked, "Do you agree to use SIMANTAP in academic system?" The result show that there was one person $(5 \%)$ who was strongly disagree, two persons $(10 \%)$ who were disagree, six persons $(30 \%)$ were agree, and 11 persons $(55 \%)$ were strongly agree. Hence, most of the university representatives agreed to use SIMANTAP as a form of academic service.

Figure 8 depicts the survey result on the university ability in operating computer and using internet. There was one person $(5 \%)$ who admitted to have poor ability, four persons $(20 \%)$ admitted to have good skill, and 15 persons (75\%) admitted to have excellent skill. In meaning that, the majority of SIMANTAP users of the university had good ability in operating computer and using internet.

There were 100 students who were surveyed to identify their satisfaction in using academic services based on 10 aspects in the process of academic services. The survey result showed that, as depicted in Figure 9, of the 10 aspects, five aspects got satisfying assessment from all $(100 \%)$ of the students. These five aspects include new student admission application system online, data input process services for new students using the online system, clear procedures for registering new students through the website, direct payment application system services, and entrance examination services for new students using a computer-based exam application system.

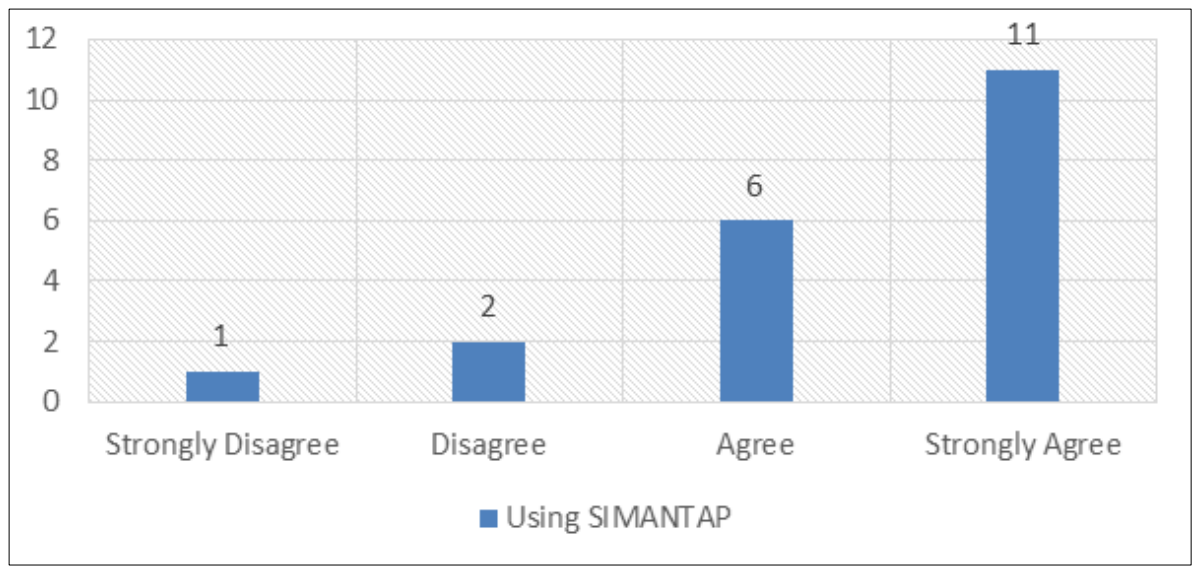

Figure 7. Interests in Using SIMANTAP

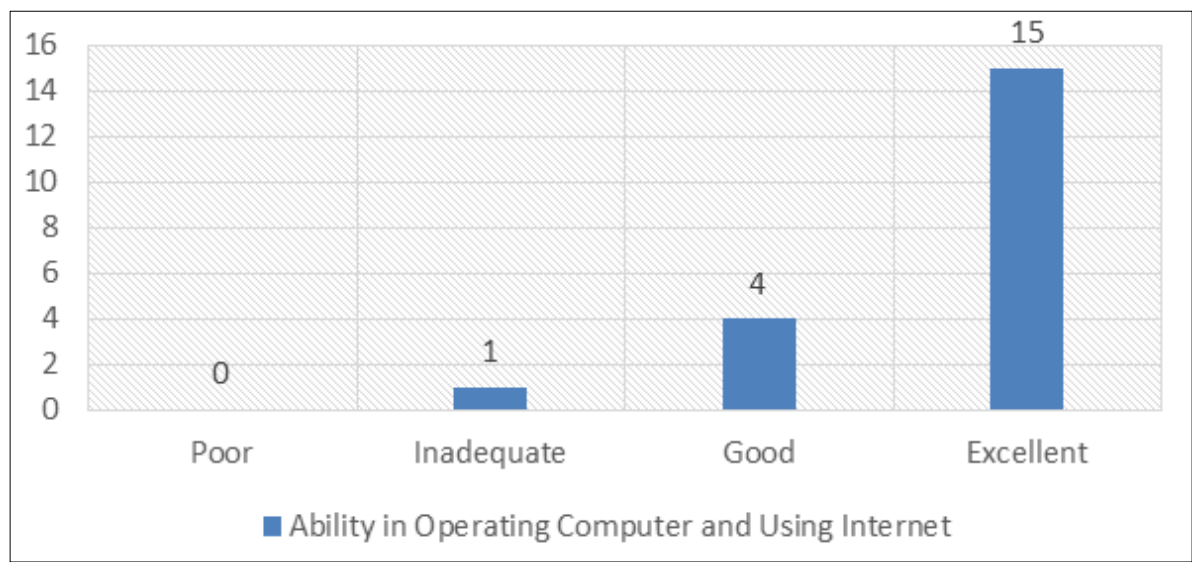

Figure 8. University Ability to Operate Computer and Use Internet 


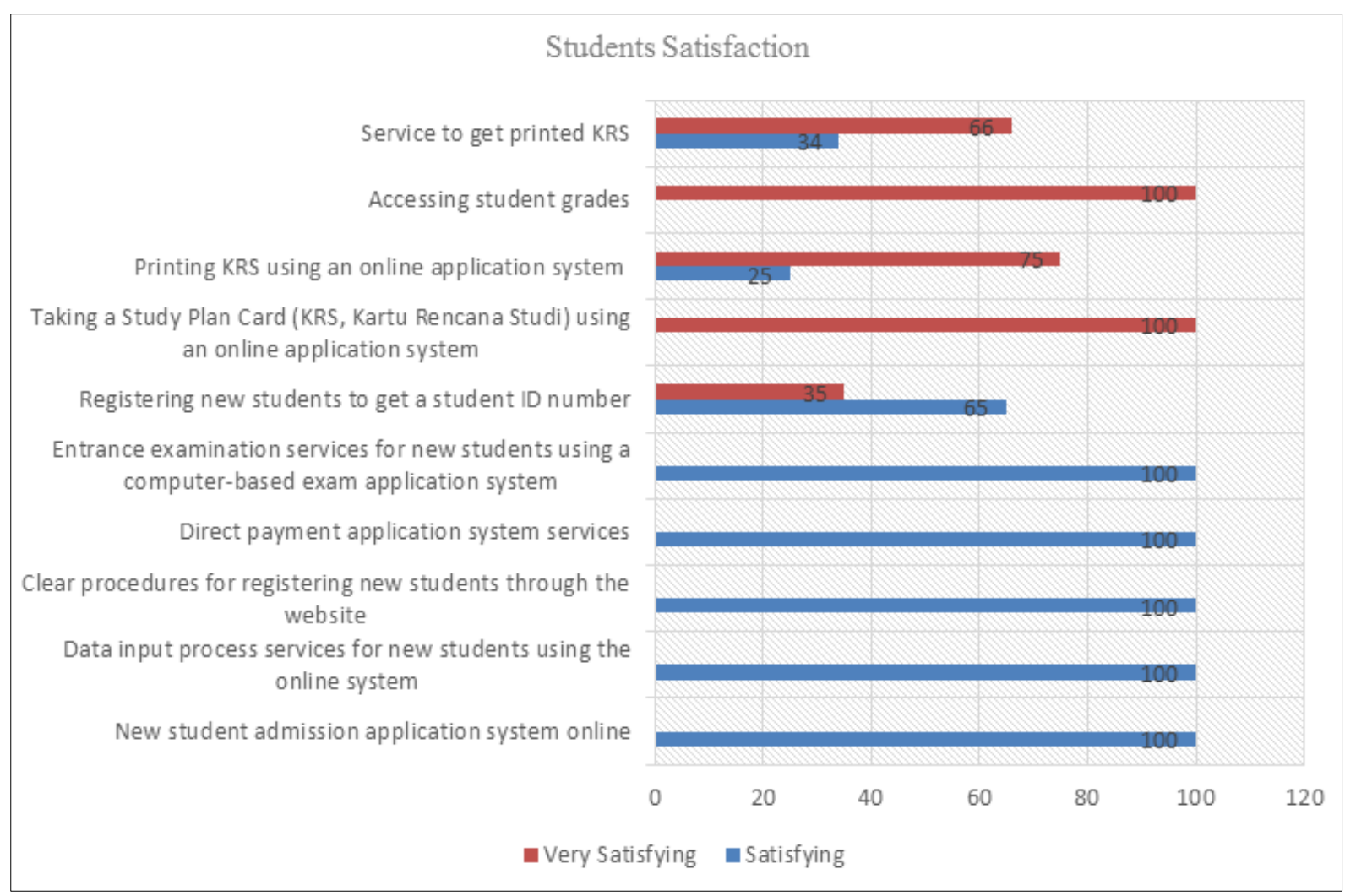

Figure 9. Students' Satisfaction on SIMANTAP

However, there were five other aspects obtaining varied responses from the students. In the aspect of the process of registering new students to get a student ID number was considered satisfying $(35 \%)$ and very satisfying $(65 \%)$ students. Then, in the aspect of taking a Study Plan Card (KRS, Kartu Rencana Studi) using an online application system was considered very satisfying (100\%). Next, in the aspect of printing KRS using an online application system was considered satisfying (25\%) and very satisfying (75\%). In addition, in the aspect of accessing student grades was considered very satisfying (100\%). Lastly, in the aspect of printing KRS was considered to be satisfying (34\%) and very satisfying $(66 \%)$. In other words, the academic services in IAIC environment using SIMANTAP have provided satisfying result for the students.

\section{Discussions}

The result of the development of SIMANTAP, an integrated academic service system at a university starting from the admission of new students to producing a transcript, is that it became an academic service system that is crucial enough for a university. Without using an internet-based academic service system, it has been proven that various problems arise in academic activities such as incomplete student data, difficulties in synchronizing financial data so that special online transaction designs are needed if possible (Abrazhevich, Markopoulos, \&
Rauterberg, 2009), confusion in course scheduling, and error or delay in inputting the grades. In other words, the presence of an internet-based academic service system is a primary need in the process of conducting academic activities at universities today. This means that technology has played an important role in all aspects of education (Geraedts, Boersma, \& Eijkelhof, 2006; Nokwali, Mammen, \& Maphosa, 2015; Rauscher, 2010).

Designing and developing an internet-based academic service system require a gradual and continuous process starting from designing the system or module to the stage of implementing them. This is because, basically, designing is a complex creative activity in an effort to make something new and useful (Gero, 1990; Jones, 1992). In the test to students only, it took them a minimum of six to eight months from registering as new students, taking courses, and obtaining a transcript at the end of the semester. Feedback from users is very important in the process of developing an academic service system to see how well the system operates properly and see the shortcomings. That is, users are also needed for their role in the process of developing an academic service system.

As found in the process of developing the SIMANTAP, user feedback is one of the keys to improve the system. The improvements, such as adding new menus to complete student data, registration notifications, login menus for the bank, adding lecturer codes, etc. were all done based on suggestions or problem findings when the system was tested. The role of users is also very important to test the 
strength of the system such as in an unexpected problem namely the system downtime when it was accessed simultaneously by many users. Thus, to build a good and strong system, the number of users and their needs must be carefully calculated, hence, system developers should consider an approach in building a user-centered system or website (Chevalier, Fouquereau, \& Vanderdonckt, 2009; Chevalier \& Ivory, 2003).

Good academic services can provide encouragement so that students, who also play the role of customers, are satisfied with the performance of the university. Satisfied customers are an inseparable part of successful business (Wright, 2008), and satisfied students are also very important for the success of higher education institutions (Mark, 2013). Student satisfaction in academic services can have a good impact on the image of the university itself because students can give or disseminate good information to the wider community for the services they receive. In other words, the students' perceptions are very important to evaluate how the programs run by the university are effective for them (Hatziconstantis \& Kolympari, 2016). Moreover, it is expected that good academic services supported by the use of technology can also improve the quality of courses since the system can have a good impact on the teaching process and student learning outcomes. Research has proven that technology has impacted positively in improving classroom teaching forms and teaching effectiveness (Gong, 2018; Guo \& Xu, 2016; Julia, Iswara, \& Supriyadi, 2019).

\section{Conclusions}

An integrated academic service system called SIMANTAP was created and developed to help improve the quality of academic services at a university. This system was implemented through several stages of tests, ranging from limited test, field test, to validation tests. In the implementation process, several problems and weaknesses were found, including incomplete menus that are important in the academic activities, and a weakness regarding facilities on the internet that needed improvement. These two problems were solved by fixing and adding menus to the module and changing hosting to VPS. After the SIMANTAP operates properly, it is important that the users, both students and university staff, have knowledge and become accustomed to the internet-based academic service system so that the SIMANTAP can be used or utilized properly to support various academic service activities.

\section{Acknowledgements}

The researcher would like to thank the supervisors who have directed this research. Gratitude is also given to the Education Administration Department of Universitas
Pendidikan Indonesia for facilitating and supporting this research process.

\section{REFERENCES}

[1] Abrazhevich, D., Markopoulos, P., \& Rauterberg, M. (2009). Designing internet-based payment systems: Guidelines and empirical basis. Human-Computer Interaction, 24(4), 408-443.

[2] Ahn, T., Ryu, S., \& Han, I. (2007). The impact of Web quality and playfulness on user acceptance of online retailing. Information \& management, 44(3), 263-275.

[3] Akbaba, A. (2006). Measuring service quality in the hotel industry: A study in a business hotel in Turkey. International journal of hospitality management, 25(2), 170-192.

[4] Amiel, T., \& Reeves, T. C. (2008). Design-based research and educational technology: Rethinking technology and the research agenda. Journal of educational technology \& society, 11(4), 29-40.

[5] Anderson, D. S., Johnson, R., \& Saha, L. J. (2002). Changes in academic work: Implications for universities of the changing age distribution and work roles of academic staff: Department of Education Science and Training.

[6] Au, N., Ngai, E. W., \& Cheng, T. E. (2002). A critical review of end-user information system satisfaction research and a new research framework. Omega, 30(6), 451-478.

[7] Bailey, J. E., \& Pearson, S. W. (1983). Development of a tool for measuring and analyzing computer user satisfaction. Management science, 29(5), 530-545.

[8] Ballantine, J., Bonner, M., Levy, M., Martin, A., Munro, I., \& Powell, P. L. (1996). The 3-D model of information systems success: the search for the dependent variable continues. Information Resources Management Journal (IRMJ), 9(4), 5-15.

[9] Baroudi, J. J., \& Orlikowski, W. J. (1988). A short-form measure of user information satisfaction: a psychometric evaluation and notes on use. Journal of management information systems, 4(4), 44-59.

[10] Bhattacherjee, A. (2001). Understanding information systems continuance: an expectation-confirmation model. MIS quarterly, 351-370.

[11] Bouman, M., \& Van der Wiele, T. (1992). Measuring service quality in the car service industry: building and testing an instrument. International Journal of Service Industry Management, 3(4), 4-16.

[12] Brancheau, J. C., \& Brown, C. V. (1993). The management of end-user computing: status and directions. ACM Computing Surveys (CSUR), 25(4), 437-482.

[13] Burnett, P., Shemroske, K., \& Khayum, M. (2014). Disrupting Faculty Service: Using Technology to Increase Academic Service Productivity. Administrative Issues Journal: Connecting Education, Practice, and Research, 4(2), 48-58. 
[14] Caruana, A. (2002). Service loyalty: The effects of service quality and the mediating role of customer satisfaction. European journal of marketing, 36(7/8), 811-828.

[15] Chevalier, A., Fouquereau, N., \& Vanderdonckt, J. (2009). The influence of a knowledge-based system on designers' cognitive activities: a study involving professional web designers. Behaviour \& Information Technology, 28(1), 45-62.

[16] Chevalier, A., \& Ivory, M. Y. (2003). Web site designs: Influences of designer's expertise and design constraints. International Journal of Human-Computer Studies, 58(1), $57-87$.

[17] Conway, M., \& Dobson, I. (2003). Fear and loathing in university staffing. Higher Education Management and Policy, 15(3), 123-133.

[18] Davis, F. D. (1989). Perceived usefulness, perceived ease of use, and user acceptance of information technology. MIS quarterly, 319-340.

[19] Del-Palacio, I., Sole, F., \& Berbegal, J. (2011). Which services support research activities at universities? The Service Industries Journal, 31(1), 39-58.

[20] DeLone, W. H., \& McLean, E. R. (1992). Information systems success: The quest for the dependent variable. Information systems research, 3(1), 60-95.

[21] DeLone, W. H., \& McLean, E. R. (2002). Information systems success revisited. Paper presented at the Proceedings of the 35th Annual Hawaii International Conference on System Sciences.

[22] Delone, W. H., \& McLean, E. R. (2003). The DeLone and McLean model of information systems success: a ten-year update. Journal of management information systems, 19(4), 9-30.

[23] Diavastis, I., Anagnostopoulou, E., Drogalas, G., \& Karagiorgos, T. (2016). The interaction effect of accounting information systems user satisfaction and Activity-Based Costing use on hotel financial performance: Evidence from Greece. Accounting and Management Information Systems, 15(4), 757.

[24] Dillon, A., \& Morris, M. G. (1996). User acceptance of new information technology: theories and models. In: Medford, NJ: Information Today.

[25] Doll, W. J., \& Torkzadeh, G. (1988). The measurement of end-user computing satisfaction. MIS quarterly, 259-274.

[26] Doll, W. J., \& Torkzadeh, G. (1991). The measurement of end-user computing satisfaction: theoretical and methodological issues. MIS quarterly, 5-10.

[27] Dominguez-Whitehead, Y. (2018). Non-academic support services and university student experiences: adopting an organizational theory perspective. Studies in Higher Education, 43(9), 1692-1706.

[28] Eagle, L., \& Brennan, R. (2007). Are students customers? TQM and marketing perspectives. Quality assurance in education, 15(1), 44-60.

[29] Ein-Dor, P., \& Segev, E. (1978). Organizational Context and the Success of Management Information Systems. Management science, 24(10), 1064-1077. doi: $10.1287 / \mathrm{mnsc} .24 .10 .1064$

[30] Gable, G. G., Sedera, D., \& Chan, T. (2008), Re-conceptualizing information system success: The IS-impact measurement model. Journal of the association for information systems, 9(7), 18.

[31] Galletta, D. F., \& Lederer, A. L. (1989). Some cautions on the measurement of user information satisfaction. Decision sciences, 20(3), 419-434.

[32] Geraedts, C., Boersma, K. T., \& Eijkelhof, H. M. (2006). Towards coherent science and technology education. Journal of Curriculum Studies, 38(3), 307-325.

[33] Gero, J. S. (1990). Design prototypes: a knowledge representation schema for design. AI magazine, 11(4), 26-26.

[34] Gong, Y. (2018). Innovative English Classroom Teaching Based on Online Computer Technology in Rural Middle and Primary Schools. International Journal of Emerging Technologies in Learning (iJET), 13(10), 4-14.

[35] Gregor, S. (2006). The nature of theory in information systems. MIS quarterly, 611-642.

[36] Guilbault, M. (2016). Students as customers in higher education: reframing the debate. Journal of Marketing for Higher Education, 26(2), 132-142.

[37] Guimaraes, T., \& Igbaria, M. (1997). Client/Server System Success: Exploring the Human Side. Decision sciences, 28(4), 851-876. doi:10.1111/j.1540-5915.1997.tb01334.x

[38] Guo, Z., \& Xu, L. (2016). Study on the integration mode of computer network technology and college English curriculum. International Journal of Emerging Technologies in Learning (iJET), 11(08), 40-46.

[39] Hatziconstantis, C., \& Kolympari, T. (2016). Student perceptions of Academic Service Learning: Using mixed content analysis to examine the effectiveness of the International Baccalaureate Creativity, Action, Service programme. Journal of Research in International Education, 15(3), 181-195

[40] Hevner, A. R., March, S. T., Park, J., \& Ram, S. (2004), Design science in information systems research. MIS quarterly, 75-105.

[41] Hossain, M. J., \& Ahmed, S. Z. (2014). An investigation of service expectations: developing and validating an alternative scale for service quality assessment in academic libraries. International Information \& Library Review, 46(1-2), 21-30.

[42] Hussain, Z., Taylor, A., \& Flynn, D. (2004). A case study of the process of achieving legitimation in information systems development. Journal of Information Science, 30(5), 408-417.

[43] Ishman, M. D. (1996). Measuring information success at the individual level in cross-cultural environments. Information Resources Management Journal (IRMJ), 9(4), 16-28.

[44] James, P. (2002). The enterprise university: Power, governance and reinvention in Australia. Academe, 88(1), 71.

[45] Jang, J.-H., Kim, J.-K., \& Hwang, Y.-H. (2006). Influence of 
hotel information system quality on system use and user satisfaction. Journal of Quality Assurance in Hospitality \& Tourism, 7(3), 41-58.

[46] Jones, J. C. (1992). Design methods: [with new prefaces and additional texts]: Wiley and Son.

[47] Julia, J., Iswara, P. D., \& Supriyadi, T. (2019). Redesigning and Implementing Traditional Musical Instrument in Integrated Technology Classroom. International Journal of Emerging Technologies in Learning, 14(10), 75-87. doi:https://doi.org/10.3991/ijet.v14i10.10197

[48] Kettinger, W. J., \& Lee, C. C. (1994). Perceived service quality and user satisfaction with the information services function. Decision sciences, 25(5 - 6), 737-766.

[49] Kettinger, W. J., \& Lee, C. C. (1997). Pragmatic perspectives on the measurement of information systems service quality. MIS quarterly, 223-240.

[50] Knight-McKenna, M., Hollingsworth, H. L., \& Ammerman, N. (2019). Fostering partnerships with families: academic service-learning in the Little Village. Journal of Early Childhood Teacher Education, 40(2), 57-73.

[51] Lee, M. K., \& Pow, J. (1996). Information access behaviour and expectation of quality: two factors affecting the satisfaction of users of clinical hospital information systems Journal of Information Science, 22(3), 171-179.

[52] Legris, P., Ingham, J., \& Collerette, P. (2003). Why do people use information technology? A critical review of the technology acceptance model. Information \& management, 40(3), 191-204.

[53] Marginson, S., \& Considine, M. (2000). The enterprise university: Power, governance and reinvention in Australia: Cambridge University Press.

[54] Mark, E. (2013). Student satisfaction and the customer focus in higher education. Journal of Higher Education Policy and Management, 35(1), 2-10.

[55] Mason, R. O. (1978). Measuring information output: A communication systems approach. Information \& management, 1(4), 219-234.

[56] McInnis, C. (1998). Academics and professional administrators in Australian universities: Dissolving boundaries and new tensions. Journal of Higher Education Policy and Management, 20(2), 161-173.

[57] Miller, J., \& Doyle, B. A. (1987). Measuring the effectiveness of computer-based information systems in the financial services sector. MIS quarterly, 107-124.

[58] Moore, G. C., \& Benbasat, I. (1991). Development of an instrument to measure the perceptions of adopting an information technology innovation. Information systems research, 2(3), 192-222.

[59] Myers, B. L., Kappelman, L. A., \& Prybutok, V. R. (1997). A comprehensive model for assessing the quality and productivity of the information systems function: toward a theory for information systems assessment. Information Resources Management Journal (IRMJ), 10(1), 6-26.

[60] Nelson, R. R., Todd, P. A., \& Wixom, B. H. (2005). Antecedents of information and system quality: an empirical examination within the context of data warehousing. Journal of management information systems, 21(4), 199-235.

[61] Nokwali, M. P., Mammen, K. J., \& Maphosa, C. (2015). How is Technology Education Implemented in South African Schools? Views from Technology Education Learners. International Journal of Educational Sciences, 8(3), 563-571.

[62] Petter, S., DeLone, W., \& McLean, E. R. (2013). Information systems success: The quest for the independent variables. Journal of management information systems, 29(4), 7-62.

[63] Pitman, T. (2000). Perceptions of academics and students as customers: A survey of administrative staff in higher education. Journal of Higher Education Policy and Management, 22(2), 165-175.

[64] Pitt, L. F., Watson, R. T., \& Kavan, C. B. (1995). Service quality: a measure of information systems effectiveness. MIS quarterly, 173-187.

[65] Rai, A., Lang, S. S., \& Welker, R. B. (2002). Assessing the validity of IS success models: An empirical test and theoretical analysis. Information systems research, 13(1), 50-69.

[66] Rauscher, W. (2010). Knowledge-generating activities on which technology education students draw when they design and make artefacts. African Journal of Research in Mathematics, Science and Technology Education, 14(1), 85-98.

[67] Robertson, J., \& Bond, C. H. (2001). Experiences of the relation between teaching and research: what do academics value? Higher Education Research \& Development, 20(1), 5-19.

[68] Romainville, M. (1996). Teaching and Research at University: A Difficult Pairing. Higher Education Management, 8(2), 135-144.

[69] Ruhyana, N. F., \& Aeni, A. N. (2019). Effect of Educational Facilities and Infrastructure in Primary Schools on Students' Learning Outcomes. Mimbar Sekolah Dasar, 6(1), 43-54. doi: https://doi.org/10.17509/mimbar-sd.v6i1.15225

[70] Saarinen, T. (1996). An expanded instrument for evaluating information system success. Information \& management, 31(2), 103-118.

[71] Sabherwal, R., Jeyaraj, A., \& Chowa, C. (2006). Information System Success: Individual and Organizational Determinants. Management science, 52(12), 1849-1864. doi: $10.1287 / \mathrm{mnsc} .1060 .0583$

[72] Seddon, P. B. (1997). A respecification and extension of the DeLone and McLean model of IS success. Information systems research, 8(3), 240-253.

[73] Seddon, P. B., Staples, S., Patnayakuni, R., \& Bowtell, M. (1999). Dimensions of information systems success. Communications of the Association for Information Systems, 2(1), 20.

[74] Sharrock, G. (2000). Why students are not (just) customers (and other reflections on life after George). Journal of Higher Education Policy and Management, 22(2), 149-164.

[75] Small, K. (2008). Relationships and reciprocality in student 
and academic services. Journal of Higher Education Policy and Management, 30(2), 175-185.

[76] Srinivasan, A. (1985). Alternative measures of system effectiveness: associations and implications. MIS quarterly, 243-253.

[77] Straub, D., Limayem, M., \& Karahanna-Evaristo, E. (1995). Measuring system usage: Implications for IS theory testing. Management science, 41(8), 1328-1342.

[78] Sunaengsih, C., Anggarani, M., Amalia, M., Nurfatmala, S., \& Naelin, S. D. (2019). Principal Leadership in the Implementation of Effective School Management. Mimbar Sekolah Dasar, 6(1), 79-91.doi:https://doi.org/10.17509/mimbar-sd.v6i1.15200

[79] Szekeres, J. (2006). General staff experiences in the corporate university. Journal of Higher Education Policy and Management, 28(2), 133-145.

[80] Thong, J. Y. L. (1999). An Integrated Model of Information Systems Adoption in Small Businesses. Journal of management information systems, 15(4), 187-214. doi:10.1080/07421222.1999.11518227

[81] Urbach, N., \& Müller, B. (2012). The updated DeLone and McLean model of information systems success. In Information systems theory (pp. 1-18): Springer.

[82] Venkatesh, V., Morris, M. G., Davis, G. B., \& Davis, F. D. (2003). User Acceptance of Information Technology: Toward a Unified View. MIS quarterly, 27(3), 425-478. doi: $10.2307 / 30036540$

[83] Wade, M., \& Hulland, J. (2004). The resource-based view and information systems research: Review, extension, and suggestions for future research. MIS quarterly, 28(1), 107-142.

[84] Weaver, W., \& Shannon, C. E. (1949). The Mathematical Theory of Communication (Urbana, IL. Illinois, University of Illinois.

[85] Winefield, A. H., Gillespie, N., Stough, C., Dua, J., \& Hapuararchchi, J. (2002). Occupational stress in Australian universities: A national survey. National Tertiary Education Union Melbourne,

[86] Wright, R. E. (2008). Targeting, segmenting and positioning the market for college students to increase customer satisfaction and overall performance. College Student Journal, 42(3), 891-895. 